\title{
The Lukan covenant concept: The basis of Israel's mandate in Luke-Acts
}

\begin{tabular}{|c|c|}
\hline \multicolumn{2}{|c|}{$\begin{array}{l}\text { Authors: } \\
\text { Frank Kovacs }{ }^{1} \\
\text { John Gosling } \\
\text { Francois Viljoen }{ }^{1}\end{array}$} \\
\hline \multicolumn{2}{|c|}{$\begin{array}{l}\text { Affiliations: } \\
{ }^{1} \text { Faculty of Theology, } \\
\text { Potchefstroom Campus, } \\
\text { North-West University, } \\
\text { South Africa }\end{array}$} \\
\hline \multicolumn{2}{|c|}{$\begin{array}{l}\text { Correspondence to: } \\
\text { Francois Viljoen }\end{array}$} \\
\hline \multicolumn{2}{|c|}{$\begin{array}{l}\text { Email: } \\
\text { viljoen.francois@nwu.ac.za }\end{array}$} \\
\hline \multicolumn{2}{|c|}{$\begin{array}{l}\text { Postal address: } \\
\text { Private Bag X6001, } \\
\text { Potchefstroom 2520, } \\
\text { South Africa }\end{array}$} \\
\hline \multicolumn{2}{|c|}{$\begin{array}{l}\text { Dates: } \\
\text { Received: } 14 \text { Nov. } 2011 \\
\text { Accepted: } 02 \text { Feb. } 2013 \\
\text { Published: } 16 \text { Apr. } 2013 \\
\text { Republished: } 03 \text { May } 2013\end{array}$} \\
\hline \multicolumn{2}{|c|}{$\begin{array}{l}\text { How to cite this article: } \\
\text { Kovacs, F., Gosling, J. \& } \\
\text { Viljoen, F., 2013, 'The Lukan } \\
\text { covenant concept: The basis } \\
\text { of Israel's mandate in Luke- } \\
\text { Acts', Verbum et Ecclesia } \\
\text { 34(1), Art. \#697, } 9 \text { pages. } \\
\text { http://dx.doi.org/10.4102/ } \\
\text { ve.v34i1.697 }\end{array}$} \\
\hline \multicolumn{2}{|c|}{$\begin{array}{l}\text { Note: } \\
\text { This article was republished } \\
\text { with the correct spelling for } \\
\text { the author Frank Kovacs. }\end{array}$} \\
\hline \multicolumn{2}{|c|}{$\begin{array}{l}\text { Copyright: } \\
\text { (C) 2013. The Authors. } \\
\text { Licensee: AOSIS } \\
\text { OpenJournals. This wo } \\
\text { is licensed under the } \\
\text { Creative Commons } \\
\text { Attribution License. }\end{array}$} \\
\hline \multicolumn{2}{|l|}{ Read online: } \\
\hline 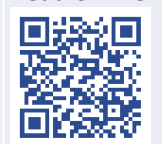 & $\begin{array}{l}\text { Scan this QR } \\
\text { code with your } \\
\text { smart phone or } \\
\text { mobile device } \\
\text { to read online. }\end{array}$ \\
\hline
\end{tabular}

Upon analysis of Luke's Gospel and the Acts of the Apostles conjoined theoretically in the reading event, the basis of Israel's mandate became pellucid in Lukan terms. This kind of analysis required the viable assumption of conceptual unity behind the gospel and Acts, and the application of the appropriate methodological approach of structural criticism. Morphosyntactical analysis yielded positive results that suggested text-based evidence concerning Israel's calling. It was observed that the covenant concept presented in its operative aspect of service to God was the basis of Israel's mandate. Luke and Acts appeared to agree that Israel was called to live in obedient righteousness following the call to Abraham to walk blamelessly. The covenant-based calling was affirmed by Isaianic allusions to Israel's mandate to be a light to the nations in her righteousness. The mandate's disruption had disabled Israel, requiring the resolution of God's deliverance.

\section{Introduction}

Greimasian morpho-syntactic analysis of Luke's gospel and the Acts of the Apostles reveals the Lukan covenant concept in its operative aspect of service, which is also the basis for Israel's mandate.

\section{The feasibility of the collective analysis of Luke and Acts}

The value of narrative critical considerations for the textual analysis of biblical material is obvious to modern scholarship. In the field of Lukan studies the wealth of scholarship on the narrativity of Luke's Gospel and Acts of the Apostles attests to this statement. The results will not be rehearsed here. Instead, this article explores the degree of narrativity in the Lukan writings and its implications for meaning by countenancing the influence of conceptual unity. In a 1988 article, Beverly Roberts Gaventa emphasised the importance of conceptual unity for a comprehensive understanding of the theology of Acts (Gaventa 1988:149-157). Gaventa's position corresponds with Paul Minear's argument that a proper apprehension of the conceptual world of the writer is important for understanding text communication (Minear 1976:6). Minear and Gaventa's observations are relevant not only for individual books but also for a collection of writings with subject matter demonstrably and deliberately in common (Frye 1990). The fact that scholarship perceives some form of literary connectedness, ranging from the trivial to the substantial, between Luke's gospel and Acts (see Bird 2007; Spencer 2007) suggests, according to Northrop Frye's logic, the existence of a text-based 'conceptual unity' governing these writings (Frye 1990:xii). Frye's analysis of the Bible's function in English literature has led him to reject the perception that the Bible is a grab-bag anthology in favour of the view that it is a source of a period's 'mythology' (nota bene Frye's definition of mythology) which expresses a meta-belief informed within a cultural and psychological context (Frye 1990:xii-xxiii, 31-52). Although he views the Bible as a library of very different books, Frye deems conceptual unity necessary for understanding the story communicated by texts with (albeit, according to Frye, culturally and psychologically determined) literary affinity (Frye 1990:xii).

Precedent for analysing Luke's Gospel and Acts together under the governance of conceptual unity can be found as far back as in the writings of Dionysius of Halicarnassus. His logic provides a fundamental guide for modern scholarship in that, as he was not the only one to note, the supreme importance of the 'standardised' unifying form that governed historical writing consisted of an appropriate beginning and ending (Heath 1989:77-81). Dionysius implied that this applied to individual works as well as a collection of works. The significance of conceptual unity for modern scholarship is seen clearly in its acceptance by a number of scholars such as R. Morgenthaler (1949), M.C. Parsons (1987), J. Dupont (1978), G. Wasserberg (1998), L. Alexander (1999), M.P. Bonz (2000), P. Mallen (2008), and C.B. Puskas (2009). As a result it provides a unified precedent for a meta-story delimited beyond compositional units. 
Conceptual unity, being a prevalent idea, commends itself as a fundamental assumption for serious consideration as one comes to analyse Luke's Gospel and Acts together. Lukan scholarship, however, seems to recognise the potential results from this type of a priori method very cautiously, perhaps because of the genre-associated methodological challenges which are thereby brought to the analytic task. This article attempts to address scholarship's caution. It observes that Luke's Gospel and Acts, if conjoined theoretically in the reading event, that is if a conceptual unity is assumed, can be analysed together morpho-syntactically according to structural-critical principles, applying particularly the Modèle actantiel (Calloud 1973), the Actantial Model of A.J. Greimas (1983). This methodology identifies and extracts a logically dependent structure across the two books. The suitability of this type of analysis hinges on the inseparability of the text's plot from a clearly developed story (fabula), and the programmatic 'elucidation of certain characteristics of the overall text' (Patte 1990:10).

\section{Merits and method of a structural- critical approach}

The following scholarship has constructively employed structural criticism to Bible texts: Jean Calloud (1979), Daniel Patte and Judson F. Parker (1980), Matthias Wenk (2000), Richard B. Hays (2002), Robin Routledge (2004) and Samuel Byrskog (2008). The following comments about the merit and method of this approach for biblical scholarship can be derived from their work.

Structural criticism is most helpful, and therefore quite valuable, in elucidating the major implication of the conceptual unity of Luke's Gospel and Acts simply because it is able to treat large text units with results that show diminished fragmentation. Admittedly the approach has 'an element of circularity' (Routledge 2004:183-204), which Jean Calloud explains is because structural 'analyse avance sur plusieurs plans à la fois et que, souvent, des obscurités persistantes à un niveau sont réduites par une prévisin des étapes ultérieures' [structural analysis proceeds on many levels at the same time, and often obscurities on one level are clarified by an anticipation of subsequent steps] (Calloud 1973:14). Advantageously, however, this method prevents the exegete from being overrun by a multitude of possible directions for inquiry and fosters analysis within view of the text's main theme (Routledge 2004:203). N.T. Wright also sees deliberate thoroughness as a significant characteristic of structuralcritical methodology (1992:70).

A specific reason for the distinguishing application of a structural-critical approach rests on the fundamental observation that a narrative system develops according to a culturally informed translinguistic sequence (Greimas 1971:793). This in turn results in the considerable extent to which the story (fabula or metadiegetic narrative) underneath or behind a large body of text can be accessed. Previous Lukan research has indeed noted the presence of a background story to Luke's Gospel and/or the Acts of the Apostles, and concepts such as necessity, divine plan and fulfilment of promises of salvation are vital for its identification. Yet the explicated meaning of these concepts as a whole within the biblical history of Israel seems rather unsatisfying. The various methodologies of the Redaction, Composition Criticism, Narrative, Rhetorical, Sociological and Apologetic Approaches all seem to determine the extent to which smaller sections of a text or parts of a text relate to one another as a larger unit on the level of the plot (diegetic level). A comparison of interpretations of the larger unit will show a variegated picture, as each interpretation may possess its own anomalies. Structural methodology makes the assumption that the larger text (on plot or diegetic level) corresponds to a formulaic integration of its parts into an expansive organic and teleologically defined whole on the level of the story (fabula or metadiegetic level); this observation assists, and may even guide, the analysis of smaller units with a view to their potential relation to one another. Furthermore, the analysis of smaller units may utilise the strengths of other methodologies as needed. The heuristic value of the structural-critical approach, in this case the morphosyntactical phase of analysis, lies in the understanding that a formulaic story pattern governs the relation of its narrative parts in terms of overall purpose, which in turn generates the nature of the story, and ideally decreases the overall possibility of fragmented or disharmonious results from exegesis. A survey of the research seems to indicate that Luke's Gospel and Acts have not been subjected to this type of methodology as a unit with the goal of discerning the story behind the two volumes, that is, Israel's story, its mandate and the basis of that mandate.

This article will follow the morpho-syntactic approach of Greimas's structural methodology (1983) as interpreted and synthesised by Hays (2002). Calloud is also a useful reference (1973). The methodological approach of structural criticism is somewhat variegated and Hays's presentation resolves this concern.

The construction of sequences and syntagms begins in the reading event with the elucidation of reading units called lexies, which can be defined as units wherein an encompassing fundamental happens and relation is created (Calloud 1973:13). This is perhaps the simplest but also the most challenging step in the method of structural criticism, as a narrative needs to be reduced to its normative fundamentals of actors and processes (Calloud 1973:13-14). From this identification process emerges the sequences and syntagms.

\section{Structural analysis of Luke's Gospel and the Acts of the Apostles}

The Gospel of Luke (ch. 1:5 - ch. 24:53) together with the Acts of the Apostles (ch. 1:3-ch. 28:31) is taken as the text to be analysed. The sections Luke 1:1-4 and Acts 1:1-2 are not included as they communicate the perceptible testimonial function of the narrator. Structural-critical methodology recognises the existence of structure in narrative, that is, 
a system of logical narrative development of a hierarchy of narrative programmes (Patte \& Patte 1978:24-25). As mentioned above, this system of narrative development conforms to a culturally informed translinguistic sequence (Greimas 1971:793), consisting of a beginning, middle and ending or, in structuralist terms, an initial, topical and final sequence. A mandate is disrupted in the initial sequence; it is resolved in the topical sequence (or not); and it is re-addressed in the final sequence. Each sequence contains three syntagms (see Figure 1) that must occur in logical order: the contract syntagm (CS1, CS2) - protagonist charged to perform a task - the disjunction or conjunction syntagm (DS) - protagonist carries out the task - and the performance syntagm (PS1, PS2, PS3) - protagonist fulfils or fails the task (Hays 2002:85-87; Greimas 1983:239-240).

To this syntagmatic system belong six actants, agents and objects, elements of the narrative and the actantial model that systematises the relation between them. Finally, the Actantial Model gives a stereoscopic view of the sequence as a whole, the combination of the C, D/C, and P syntagms (see Figure 2).

There is only one Actantial Model for each sequence, as shown in Figure 3 (Hays 2002:93).

Due to the space restrictions of this article, the presence of these sequences in Luke and Acts cannot be elucidated in full. Only the initial sequence and Israel's mandate will therefore be presented, even though it is irregular to view the sequences without reference to each other.

\section{Initial sequence}

The initial sequence introduces a situation of lack where an order or mandate has been disrupted. That something had for some time not been as it should be in the life of Israel, and that it was affecting its current and future state, is indicated clearly in the angelic announcement to Zechariah (Lk 1:16-17), the Benedictus (Lk 1:71-75) and the Stephen Speech (Ac 7:51-53). These texts and those presented below articulate a basic common lexie from which the initial sequence is derived. God had called Israel but Israel had failed to fulfil that calling. The initial sequence may, however, precede plotted time and therefore may not be positioned chronologically or may not be a unified section of text (possibly may not even be complete). This is indeed the case in the Lukan writings, as the infancy narrative begins the topical sequence, relating the problem resolution. Detection of the initial sequence is left to investigation. Fundamental morpho-syntactical components of the background story or metadiegetic narrative (Prince 2003:50) must be extracted and examined in order to identify this sequence.

\section{Extraction of metadiegetic narrative's syntactical components}

Assembling the initial sequence in this case involves a basic reconstruction of the background story or fabula particularly the metadiegetic narrative that precedes plotted time - and should reveal a vignette of Israel's moral condition and thereby, amongst other things, the situation of lack and the initial mandate. Writing for the Interdisciplinary Center for Narratology at the University of Hamburg, Didier Coste and John Pier summarise Gérard Genette's observations: there are three basic relations by which metadiegetic level is bound to primary or diegetic narrative level:

... (a) explanatory, when there is a link of direct causality between the events of the diegesis and those of the metadiegesis; (b) thematic, by way of contrast or analogy between levels ... with a possible effect of the metadiegesis on the diegetic situation; (c) narrational, when the act of (secondary) narrating merges with the present situation ... (Coste \& Pier 2010:n.p.)

Genette (1990:92-94) later expanded these three relations to six. By examining the appropriate relations a background story should therefore emerge.

The extraction itself, however, requires some facilitation if the initial sequence with the disruption of the original mandate is to be elucidated. Conflict scenes, pronouncements stories and typological allusions offer guidance. The following list is not intended to be exhaustive, but may serve as a representative extraction.

\begin{tabular}{|c|c|c|c|c|c|c|c|c|}
\hline \multicolumn{3}{|c|}{ Initial sequence } & \multicolumn{3}{|c|}{ Topical sequence } & \multicolumn{3}{c|}{ Final sequence } \\
\hline $\mathrm{C}$ & $\mathrm{D} / \mathrm{C}$ & $\mathrm{P}$ & $\mathrm{C}$ & $\mathrm{D} / \mathrm{C}$ & $\mathrm{P}$ & $\mathrm{C}$ & $\mathrm{D} / \mathrm{C}$ & $\mathrm{P}$ \\
\hline
\end{tabular}

Source: Hays, R.B., 2002, The faith of Jesus Christ: The narrative substructure of Galatians 3:1-4:11, 2nd edn., p. 85, William B. Eerdmans, Grand Rapids, MI

C, contract syntagm; D/C; disjunction/conjuction syntagm; P, performance syntagm. FIGURE 1: Syntagmatic system.

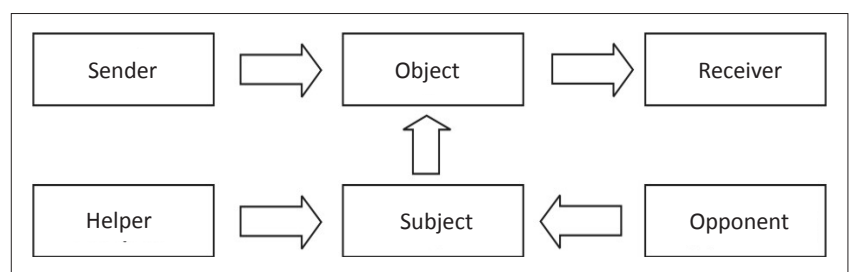

FIGURE 2: Stereoscopic view of the Actantial Model sequence as a whole.

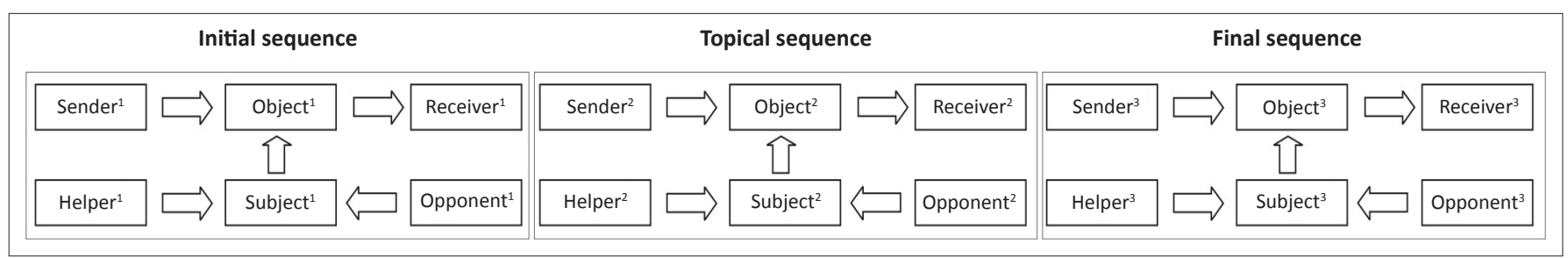

Source: Hays, R.B., 2002, The faith of Jesus Christ: The narrative substructure of Galatians 3:1-4:11, 2nd edn, p. 93, William B. Eerdmans, Grand Rapids, MI 1 , first syntagm; 2, second syntagm; 3 , third syntagm.

FIGURE 3: Actantial Model. 
Angelic announcement to Zechariah, Gospel of Luke 1:16-17: The angelic announcement to Zechariah provides the explanatory and thematic relation of diegesis to metadiegesis. John the Baptist's birth is thereby linked to the background story. The angelic announcement reveals an implicit, divine evaluation of Israel's pre-existing moral condition. They were separated from their God (revealed by their social degeneration); they were the un-unified people of God (a result of their ethical deficiency in wisdom and righteousness). This is a generational situation of lack. Fitzmyer states that the turning of the fathers to their children, a reference to Malachi 3:34, addresses 'the paternal neglect of the young in Israel', for 'Luke is hinting ... at the neglect shown by Israel of old toward those who are becoming Abraham's children' (Fitzmyer 1970:320). The reference is also found in Ben Sirah, in the 'Praise of the Fathers' section (48:10), where the context is similar. A failure of leadership seems to be related to the deficiency of upright, righteous, ethical living and thereby to the fact that Israel is no longer a unified people of God. The text suggests that leadership, particularly religious leadership, may be a good candidate for the Actantial position of 'opponent', who prevents the subject, Israel, from carrying out its mandate. This seems to fulfil the following canonical functions: PS1, the confrontation statement (there is a conflict with Israel's leadership); and PS2, domination or submission statement (the leadership subdues the people). The angelic evaluation seems to indicate the reason for the disruption of the mandate.

Benedictus, Gospel of Luke 1:71-75: The Benedictus provides an explanatory and thematic relation of diegesis to metadiegesis: why and how the ministry of Jesus will effect salvation. Zechariah under Spirit inspiration [eplêsthê pneumatos hagiou] is portrayed as a trustworthy speaker, hence his credibility is rescued and the effect of his initial unbelief is remedied. The circumstances of Zechariah's life, as well as an intertextual allusion to the Abraham cycle, the revered past and the covenant, serve to validate the Zechariah story and prologue, and also to establish the prologue as a continuation of the Abrahamic story (Litwak 2005:82-83).

The initial sequence contract (CS1, canonical function) is here given in succinct form. God will enable the people to fulfil what they have been unable to do. The births of John and Jesus herald God's redemption, salvation and deliverance from impending opposition and herald the enabling of God's people to his service, an appropriate service which is characterised by lack of fear, security, holiness and righteousness. The use of the term latreuein' refers to:

... a way of life that is really a cultic service of him. Though it denotes acts of worship, it is used analogously of the entire way in which the chosen people was to conduct itself (Fitzmyer 1970:385).

The designation of Israel as servant [paidos] in the Magnificat (1:54) reinforces their calling to serve God. The text suggests that appropriate prior service to God, the mandate of CS1, has been disrupted, prevented by opposition, and that it will be reestablished. This is only possible because God remembers his covenant and oath to Abraham (Lk 1:72-73). The reference to the Abrahamic story in verses $72-75$ seems to allude not only to the Abrahamic covenant blessing, as mentioned above, but also to God's command to Abraham: 'I am God Almighty; walk before me, and be blameless. And I will make my covenant between me and you, and will make you exceedingly numerous' (Gn 17:1-2). This seems to garner support for the concept of service, the operative aspect of the covenant, as an Actant in the initial sequence.

In Luke the Abrahamic covenant (Lk 1:71-75) is a basis of Israel's election, redemption and strength to fulfil what God had called them to (CS1), that is to serve him boldly in righteousness and holiness. This fulfils the canonical function CS2, communication or reception, in that Israel receives a helper: the calling in the Abrahamic covenant to fulfil the mandate. Deliverance from Israel's enemies (the opponents), who are preventing service to God (PS1 and PS2) is therefore requested.

Nunc Dimittis, Gospel of Luke 2:30-32: Simeon's metaphorical pronouncement of Jesus' ministry gives explanatory relation to the background story to the gospel. Simeon refers to himself as ton doulon sou, despota [Lord, your servant]. Simeon, the Lord's servant, is devout, righteous, vigilant and led by the Spirit. This not only characterises Simeon and makes credible the explanatory relation of Jesus' ministry to the Isaianic Servant Song of Isaiah 49:6, 42:6 and $46: 13$, but it also attributes specific qualities to the Lukan conception of a proper servant. Lukan concern for the servant conception becomes increasingly evident in the focalisation event of the blessing scene. The 'focalisor' Simeon's pronouncement connects the plot-event to the background story by using Old Testament terminology in the blessing scene. The scene focuses the narrative portrayal of Jesus as not just the one who saves, rescues and delivers, as presented in the Benedictus, but as one who saves as a light of revelation and glory because he is the Isaianic servant covenanted to his task. Simeon is a faithful servant, but the epitome of servant is now also brought to the fore. The reference to the Isaianic servant not only adumbrates Jesus' mission but also suggests that the condition he is to address is a perpetuation of the situation described in Isaiah, a situation characterised by darkness. Zechariah, whilst referring primarily to Israel, also avers that the tender mercy of God will bring light to those in darkness (Zch 1:78-79). This aspect of the initial sequence situation, as it points to the contract mandate prior to plotted time, is ultimately what is of prime concern.

The Isaianic quotation of the Nunc Dimittis is a direct pronouncement over the life of Jesus. However, it will be an incomplete observation if it does not consider additional evidence and intertextual allusions. When supplemented by the commissioning of Jesus' disciples at various stages, the textual evidence of the Lukan usage of Isaiah 42 and Isaiah 49 found in Acts 13:47 does not allow us to proceed without ascertaining the full import of the Isaianic quotation. A.J. Mattill's concerns and observations undergird this argument (1975). 
Isaianic servant concept and Israel's mandate: Morna Hooker is essentially correct in saying that one's understanding of the relational nature between individual and collective identity determines one's conception of the servant in Deutero-Isaiah (Hooker 1959:41-45). Whether one conceptualises the servant individually or collectively, as many contemporary scholars do (Ulrich Berges [2010:36, 38], for example, sees the Isaianic servant as a personification of the post-exilic followers of the Prophet Isaiah), the servant remains a connecting element between historical Israel and post-exilic devout groups (Berges 2010:35). Berges goes so far as to say:

... on the one hand the servant stands for Israel transformed by God himself and on the other he symbolizes the prototype of those who in Trito-Isaiah are called servants of God. (ibid:35)

Joseph Blenkinsopp's article (1995:411) supports much of Berges's argument, arguing that the post-exilic group, YHWH's servants who are identified in Isaiah 56-66, Ezra 9-10 and Malachi 3, can be linked to the disciples of the servant in Deutero-Isaiah 40-55, and that 'the literary growth of Isaiah 40-46 is related in important ways to the emergence and consolidation of a prophetic-eschatological group within post-exilic Judaism.' What is of interest for this article is that Blenkinsopp points to the 'redefinition of the office in terms of instrumentality and service' (1995:406). As such the Isaianic servant is inherently central to God's deliverance, defining the restorative event.

According to Isaiah 49:6, the Isaianic servant is to restore the tribes of Jacob after which the servant will also be a blessing to the gentiles and to the ends of the earth. Restoration is the crux of the Deutero-Isaianic agenda. According to MartinAchard (1962:9, 15), Israel's divine mission in DeuteroIsaiah is to be God's servant to whom is given the task of revealing the greatness of $\mathrm{YHWH}$ as the true God; this is why Israel was created (Is 43:7ff). Routledge echoes this general observation (2004:190). This is Israel's articulated mandate. The Isaianic corpus, however, attests that Israel transgressed the law, committing not only legal offences but deliberately rebelling. They had 'violated the covenant' (Is 24:5) because they had failed to carry out God's will for them. Restoration is therefore required if they are to fulfil their given mandate (Routledge 2004:188, 190). Restoration according to Oswalt (1986) addresses the problem that:

... proud, arrogant, sinful Israel is anything but the servant of God. Nevertheless, Israel is declared as the means though whom God's light and blessing will come to the world ... How can this Israel be that Israel? (ibid:54)

Oswalt (1986:54) observes that chapters 49 and following answer his question: God makes it possible by covenant-based unilateral action. YHWH, because of his own faithfulness, is coming to tend to Israel (Martin-Achard 1962:12, 15).

In Deutero-Isaiah, the servant is covenanted to reveal God's restoration of Israel (Martin-Achard 1962:18). God's Spirit rests on him to show the whole world that Yahweh's judgement is to forgive his people and restore them (MartinAchard 1962:29). The labour of the servant, his suffering, persecution and glorification serves this task, linking Isaiah 6 with Isaiah 53, to help the people recognise God's mercy and glory in his mission (Berges 2010:38). In this way the Isaianic servant is the light of the world (Martin-Achard 1962:18). Restored Israel's identity is, however, tied up with that of the Isaianic servant as witnesses (Berges 2010:35). They are his offspring represented in him (Berges 2010:35, 38). As MartinAchard (1962:31) states: 'It is by granting life to His People that Yahweh makes it the light to the world'. Routledge (2004) qualifies this statement by saying that:

Israel's role in the winning of the nations is not merely passive, and in the closing verses of the book we see God's people performing the somewhat unfamiliar task of going out to the nations in order to bring them back to worship God in Jerusalem (Isa. 66:18-19). (ibid:193)

This illuminates the situation of lack in which Israel was floundering disempowered, the societal deterioration of just, righteous and ethical living defined in covenant terms by Yahweh, a situation which the Isaianic servant is called to resolve (Routledge 2004:199-200).

Lukan transformation of Isaiah: The significance of the Lukan presentation of the Isaianic servant concept and the situation of lack rests upon the Lukan interpretation of Isaiah. Recognising that a somewhat particularistic tendency governed the use of Isaiah in the literature of late Second Temple Judaism, the 'subversive' intentions of Lukan Jesus become increasingly evident (Mallen 2008:53, 102-131, 133, 207). In the Gospel prologue, the transition between the two volumes and the conclusion of Acts in particular, Luke dialogues with Isaiah, causing transformations by his specific selection of passages, by developing particular themes and by the inclusive-salvational and Christ-centric application of select prophecies (Mallen 2008:99-100, 131-132). The two transformations that are the most radical are the mission of the servant and the inclusivity of salvation (Mallen 2008:99-100, 132-133, 207). Lukan salvation is inclusive because Luke applies Isaianic passages on eschatological reversal to Jewish society, critiquing accepted norms and then extending the application to include the gentiles (Mallen 2008:132). The servant's mission, Luke shows from Isaiah, is to proclaim this inclusive salvation, to fulfil obediently the mandate and vocation of Israel and to suffer and be exalted for the purpose of restoring Israel and facilitating further proclamation by his followers (Mallen 2008:129-130, 132-133). Peter Mallen's work (2008) testifies to the substantial Luke-Isaiah connection and demonstrates that Luke imbibes much of the corporate and individual aspects of the servant concept from Isaiah, transforming them with regard to his own universalising purpose of inclusive salvation (Mallen 2008:102-133, 189197). The Lukan corpus capitalises on the Isaianic oscillation between the individual and corporate identity of the servant figure role. Thus, the Initial Sequence mandate of God's people is to serve him without fear in righteousness and holiness in order that the light of God's justice and mercy may extend to the nations. The mandate seems then to consist of two closely related parts, $\mathrm{CS} 1 \mathrm{a}+\mathrm{b}$, the second being contingent on the first. The evidence seems to suggest that 
the CS1 canonical function (mandating or acceptance) can be understood as complete in this way.

The light of God's justice and mercy, then, is the 'object' to be communicated to the 'receiver', the nations. For this purpose is Israel called in the Abrahamic covenant (Actant or 'helper' role): to serve God by walking blamelessly, in just and righteous behaviour, not passively or bound by particularism, but actively seeking to engage the nations that they may also enjoy covenant blessings of mercy. With this, however, they have failed to comply. The 'object', then, that the sender wants to communicate to the receiver in the Actantial model is 'the light of God's mercy in service'; the 'receiver' being the nations.

The strength of intertextual evidence confirms Simeon's quotation from Isaiah in the Nunc Dimittis as an allusion to the mandated Isaianic servant role of Israel. Any additional Lukan references to and transformations of Isaiah in the Gospel and Acts should necessitate sustained consideration of aforesaid observations.

John the Baptist's preaching, Gospel of Luke 3:7-14: John's preaching gives the thematic relation of diegesis to metadiegesis, tying the importance of ethical living to the Abraham story and to righteousness, thereby elucidating his commission to turn the recalcitrant to the wisdom of the righteous. John's rebuke for misplaced trust in 'genealogical and cultic correctness' seems to allude to Isaiah 56-66, according to Oswalt (1991:91). This, in turn, touches on Israel's mission (CS1a+b, mandating or acceptance): by the righteous or ethical living that they are to facilitate, they are to reflect God's light so that the nations will turn to Jerusalem and to the Lord (Oswalt 1991:91-92).

Six woes at Pharisee's house, Gospel of Luke 11:37-54: Jesus relates diegesis to metadiegesis thematically by stating that his generation is like past generations who persecuted the prophets. The assertion is that Israel shares in the guilt of past generations. Paul Minear (1976:110) states 'Luke sees death as the sign under which all prophets stand, their solidarity being matched by the solidarity of all generations of persecutors.' Their denial of justice, lack of love for God and obstruction of proper leadership for the benefit of the people are clear signs of rebellion on the part of the religious leaders. Pre-existing rebellion and negligence by the leaders would fit the Actantial role of 'opponent' in the Greimas construction and also fit PS1 and PS2 canonical functions.

Exhortation to watchfulness, Gospel of Luke 12:35-40, 4148: By warning his hearers of those that oppose him and by exhorting his hearers to service, to which they have already been called as servants, Jesus links diegesis to metadiegesis thematically. In chapter 12 a distinct emphasis is laid on accountability when Jesus gives instructions on how one should live: not materialistically but seeking kingdom interests in vigilant faithfulness to Jesus, just as a servant in faithful service to the master. Jesus closes his call to service with 'panti de hõ edothê polu, polu zêtêthêsetai par' autou, kai hõ parethento polu, perissoteron aitêsousin auton' [From everyone who has been given much, much will be demanded; and from the one who has been entrusted with much, much more will be asked] (Lk 12:48), an allusion to his encounter with the scribes and Pharisees who have been entrusted with the leadership of God's people. Israel's leaders again appear to fit the function of 'opponents' in the Actantial Model. As leadership is lacking, Jesus himself teaches on serving the Lord, which includes seeking the Kingdom. God's people are called to service, the operative aspect of the Abrahamic covenant and 'helper' in the Actantial Model, and its specifics clearly govern this chapter.

Jesus' sorrow for Jerusalem, Gospel of Luke 13:34-35: H.O. Steck (1967:229) argues the logic that 'weil darin Israel gerichtet wird, ist Jerusalem als Mutter aller Israeliten angesprochen'. Jerusalem's resistance to God, as representative of Israel, precedes plotted time, as Jesus' reference to the prophets suggests. The time reference evidently refers to the Old Testament story, and in this way Jesus again relates diegesis to metadiegesis thematically. Jerusalem's resistance to God has not abated, as the use of present tense participles apokteinousa [who are killing] and lithobolousa [who are stoning] suggest. Regarding the use of the present participles Fitzmyer states that they are 'expressive of Jerusalem's everpresent attitude toward heaven-sent messengers' (1985:1036). Jesus says, 'posakis êthelêsa episunaxai ta tekna sou' [How often have I longed to gather your children together]. The word posakis [how often] occurs only once in Luke's Gospel and twice in Matthew $(18: 21 ; 23: 37)$ and intimates God's enduring merciful intentions, which had repeatedly been acted upon within the course of redemptive history. Israel is unwilling, has failed in her mandate and continues in this state, thus fitting the canonical function PS3, deprivation statement.

Stephen's speech, Acts 7:1-53 (7, 34, 35, 37-39, 42-43, 5153): The diegetic and metadiegetic narratives are related extensively, both explanatory-wise and thematically. The Stephen speech contains a fundamental metadiegetic narrative. The Abraham and Moses stories are linked in narration and form a continuous unit. The call of Abraham contains an anterior narration of God's call of Israel, which echoes that of Abraham (Ac 7:7). The call is a mandate to worship latreusousin moi [they will worship me] - canonical function CS1a. The meaning of this Old Testament concept appears to be sustained by the notion of cultic service. The narration of the call is followed by the canonical statement DS, which describes the move from Egypt to the Promised Land to fulfil the mandate amongst the nations. The Moses story is the development of the anterior narrative in the Abrahamic story (Ac 7:17). The deliverance of God (Ac 7:34) in Moses (Ac 7:35) reveals the nature and extent of God's unilateral activity but also the conflict situation and precise behaviour of Israel that disrupted the original mandate. The prophecy of Amos (Ac 7:42-43) serves as an epilogue to the narrative unit and provides divine evaluation, in the postexilic voice, of the unfortunate result (Richard 1982). Israel in Abraham had been called to worship but because they had rejected God's word they had eventually been given over to 
the worship of the 'host of heaven' or to idolatry. Hence the function of the Temple in worship is compromised by their disobedience, that is their communion with God, the essence of the covenant, is dependent on their righteousness. Herein lies the semantic fullness of the term latreuõ [worship]: it integrates worship and obedience into the conception of service. This suggests an inseparable link between worship and service or righteousness; herein can be seen canonical function PS1, PS2 and PS3. The Stephen speech metadiegesis illuminates how the original mandate was disrupted and identifies the source of Israel's 'spiritual' state as disobedience and rejection (Ac 7:39), as well as resistance of the Holy Spirit (Ac 7:51). The Holy Spirit appears to be in the situation of 'helper' in Greimas' Actantial model (the prophets are indirect agents of the Spirit), alongside God's promise in the Abrahamic covenant (Ac 7:5-6). The two render canonical function CS2. The Stephen speech achieves a link between the diegesis and the metadiegesis by linking Stephen's audience, whose actions are representative of Israel's, firmly with past generations (Ac 7:51-53). Just as Israel had resisted Moses and God (Ac 7:39), as well as his Spirit (Ac 7:51) by disobedience and sacrilege, so Stephen's generation resists Jesus, a prophet like Moses (Ac 7:37), by crucifying him (Ac 7:52) and so they resist the Holy Spirit (Ac 7:51). The current 'spiritual' state and behaviour of Israel is thus explained and is the result of a disrupted mandate to worship God (understood semantically as related to service to God) according to his living words. The Stephen speech reveals the entire initial sequence, or canonical functions CS1a, CS2, DS, PS1, PS2 and PS3.

Jerusalem council, Acts 15:15-18: James justifies Paul's activities by answering the question of gentile conversion by quoting Amos 9:11-12, and so relates diegesis to metadiegesis by explanation. There is opposition to the missionary work of Paul and the net result is that the basis of salvation comes into question: certain men from Judea teach that circumcision is required for salvation. The faith standard set through Peter is reiterated, and this allows Luke to set the background story in James's words. David's tent is fallen down and his house is in ruins, which is symbolic of God's people, and God's restorative work now makes room for the gentiles, too. The import of the Lukan Amos redactions is the clear message that God is now returning to his people according to plan, to those whom he had given over to the worship of pagan gods, as the chapter 7:42b-43 quotation of Amos 5:25-27 states, and that he has also 'promised that through Israel he would call all men to his name' (Richard 1982:49). The preexisting 'spiritual' state of God's people is one that is 'fallen', that is in 'ruin'. Not only has the Lukan redaction articulated the state of lack, but Israel's mandate is also asserted with certainty - they are to be a conduit for the gentiles' blessing. This fulfils canonical function CS1 as well as deprivation canonical function PS3.

As has been stated, this analysis is not an exhaustive one but a pellucid cross-representation of the metadiegesis or background story which precipitates the clear formation of the Initial Sequence.

\section{Synthesis of the metadiegetic narrative and the initial sequence}

The preceding analysis supports the validity of the diegesis-metadiegesis relation and postures structuralist methodology in such a way that in its application a panorama of the Lukan background story becomes comprehensible.

Investigation into Luke's Gospel and Acts yields very similar results. The Initial Sequence Contract appears to consist of God calling Israel in covenant to worship him, latreusousin moi [they will worship me] (Ac 7:7) and to serve him (Lk 1:74-75). The operative aspect of the covenant, service, immediately receives a place of primacy. The concept of worship takes on an ethical semantic, as God's expectation for Israel is to live righteously and ethically according to his word. This can be inferred from John's call to those that are Abraham's descendants and heirs of the covenant to live a righteous life (Lk 3:7-14) and from Stephen's speech which refers to the obedience to which Moses had called Israel (Ac 7:38). Indeed, Jesus' teachings on discipleship undergird this (Nelson 1994). As the infancy narrative seems to be the continuation of the Abrahamic story, the Abrahamic covenant with its promises and call to a blameless walk seems to be the basis for the call to service. This is reflected in Jesus' exhortation to proper service (Lk 12:35). Thus the call in Abraham is given as a helper along with the Holy Spirit (Ac 7:51). This understanding seems to echo the classical prophetic concept, derived primarily from Isaiah, that righteous behaviour is a witness to the nations, a light drawing them to God (Is 1:78-79; 2:32). The contractor mandate was broken by disobedience, resistance to God and rejection of his word, and this characterised Israel as wicked and in darkness, lacking righteousness and wisdom, and degenerating socially. The result is that Israel is described metaphorically as David's fallen tent. Present and past are in solidarity with one another. It is Israel's leadership across generations who are primarily responsible for this failing. 'In the Lucan setting of the canticle [Benedictus] the "enemies" would include all those who resist or refuse to accept the new form of God's salvation-history' (Fitzmyer 1970:384). They deny justice and the love of God, take away the key to knowledge and in this way offer no leadership to Israel. They are amongst the opposition to Israel. For this reason God needs to intervene, to deliver his people. This fits with what Marshall (1971:117) calls the central theme of Luke: 'For the Son of Man came to seek out and to save the lost' (Lk 19:10).

The following narrative syntagms and canonical functions can be discerned:

- $\mathbf{C S 1 a + b}$ (mandating or acceptance): The mandate is that God's people are to serve righteously and so be a light to the nations, reflecting God's greatness and mercy so as to draw the nations to him.

- CS2 (communication or reception): God has given a 'helper'; God has called Israel in the Abrahamic covenant to serve him boldly in righteousness and holiness. God also sends his Spirit (Ac 7:51).

- DS (disjunction or conjunction): Israel has left Egypt for the Promised Land to fulfil its mandate amongst the nations. 
- PS1 (confrontation): Israel is in conflict with its leaders who deny justice and knowledge, are rebellious and negligent and resist God and his Spirit, thereby effecting moral degeneration.

- PS2 (dominationor submission): The leadership subdues the people, preventing service to God and the fulfilment of the mandate; Israel is characterised by darkness, wickedness and oppression.

- PS3 (deprivation): Israel fails in its mandate and is in darkness. The prophetic rebuke witnesses to failure.

Based on this synthesis and analysis the Actantial Model for the Initial Sequence can be constructed as shown in Figure 4.

\section{Conclusion}

The assumption of the conceptual unity of Luke's Gospel and the Acts of the Apostles makes possible a structural-critical, specifically a morpho-syntactic, analysis of the two books as one large text unit. The implications of conceptual unity may be determined in this way. Analysis reveals a story of Israel that spans the two volumes. These results improve on previous Lukan research that has provided fair but limited descriptions of the story of Israel, the background story of the plots, by relying on plot-level redactional, stylistic and literary features. The initial sequence of the narrative system was extracted and the situation of lack or the mandate and its disruption were identified. The basis for the mandate was also discerned. The foregoing analysis observes a deliberate Lukan concern for Israel's responsibility to God. Not only is the covenant concept important to Luke as a basis of the offer of the Gospel (Kovács 2006), but it also features determinatively for Israel's calling - the covenant in its operative aspect of service is fundamental. The evidence suggests that Israel is called by God to serve or worship him (ethically) in a righteous life of obedience so that this life can serve as a witness to the nations of God's mercy and justice. The text, however, indicates a disruption of this mandate, and further analysis found that the religious leadership is primarily held responsible for Israel's failure to carry out its calling. The leadership's resistance to God's word and Spirit has morally impoverished Israel, resulting in social degeneration or the ruination of David's tent, symbolised in Isaianic terms of darkness, oppression and brokenness.

The extraction of this sequence fits well with Jesus' mission to resolve this disruption, in other words to 'seek out and save

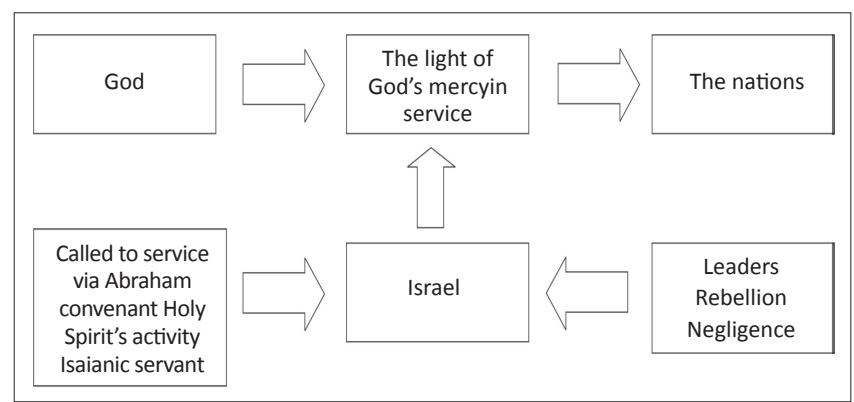

FIGURE 4: Actantial model for the initial sequence. the lost' (Lk 19:10). Jesus resolves the disruption of Israel's mandate in the topical sequence and shows how Israel is representatively restored to carry out the mandate in the final sequence. Further research should build on these results by investigating the semiotic value of the story or meta-narrative that becomes discernible when Luke and Acts are grouped together in the reading event.

\section{Acknowledgements Competing interests}

The authors declare that they have no financial or personal relationship(s) which may have inappropriately influenced them in writing this article.

\section{Authors' contributions}

F.Z.K. (North-West University, Potchefstroom Campus) was the primary author. J.G. (North-West University, Potchefstroom Campus) and F.P.V. (North-West University, Potchefstroom Campus) assisted and supervised the author.

\section{References}

Alexander, L.C.A., 1999, 'Reading Luke-Acts from back to front', in J. Verheyden (ed.), The unity of Luke-Acts, pp. 419-446, Leuven University Press, Leuven.

Berges, U., 2010, 'The literary construction of the servant in Isaiah 40-55: A discussion about individual and collective identities', Scandinavian Journal of the Old Testament 24(1), 28-38. http://dx.doi.org/10.1080/09018328.2010.491600

Bird, M.F., 2007, 'The unity of Luke-Acts in recent discussion', Journal for the Study of the New Testament 29(4), 425-448. http://dx.doi.org/10.1177/0142064X07078993

Blenkinsopp, J., 1995, 'The "servants of the Lord" in Third Isaiah: Profile of a pietistic group in the Persian epoch', in R.P. Gordon (ed.), 'The place is too small for us':
The Israelite prophets in recent scholarship, pp. 392-412, Eisenbrauns, Winona The Israe
Lake, IN.

Bonz, M.P., 2000, The past as legacy: Luke-Acts and ancient epic, Fortress Press, Minneapolis, MN

Byrskog, S., 2008, 'Christology and identity in an intertextual perspective: The glory of Adam in the narrative substructure of Paul's letter to the Romans', in B. Holmberg \& M. Winninge (eds.), Identity formation in the New Testament, Wissenschaftliche Untersuchungen zum Neuen Testament 227, pp. 1-18, Mohr Siebeck, Tübingen.

Calloud, J., 1973, Analyse structurale du récit: Elements de méthode tentations de Jésus au désert, Profac, Lyon.

Calloud, J., 1979, 'Toward a structural analysis of the Gospel of Mark', Semeia 16, 133-165.

Coste, D. \& Pier, J., 2010, Narrative levels, in P. Hühn, J.C. Meister, J. Pier \& W. Schmid (eds.), The living handbook of narratology, Hamburg University Press, Hamburg. http://hup.sub.uni-hamburg.de//hn/index.php/Narrative_Levels

Dupont, J., 1978, 'La conclusion des Actes et son rapport à l'ensemble de l'ouvrage de Luc', in J. Kremer (ed.), Les Actes des Apôtres: Traditions, redaction, théologie, pp. 359-404, Leuven University Press, Gembloux, Duculot.

Fitzmyer, J.A., 1985, The Gospel according to Luke I-XXIV, 2 vols, Doubleday, New York.

Frye, N., 1990, The great code: The Bible and literature. Markham, Penguin Books, Ontario.

Gaventa, B.R., 1988, 'Toward a theology of Acts: Reading and rereading', Interpretation 42(2), 146-157.

Genette, G., 1990, Narrative discourse revisited, transl. J.E. Lewin, Cornel University Press, Ithaca, NY.

Greimas, A.J., 1971, 'Narrative grammar: Units and levels', transl. P. Bodrock, Modern Language Notes 86(6), 793-806.

Greimas, A.J., 1983, Structural semantics: An attempt at method, transl. D. McDowell, R. Schleifer \& A. Velie, University of Nebraska Press, London.

Hays, R.B., 2002, The faith of Jesus Christ: The narrative substructure of Galatians 3:1-4:11, 2nd edn., William B. Eerdmans, Grand Rapids, MI.

Heath, M., 1989, Unity in Greek poetics, Clarendon Press, Oxford.

Hooker, M.D., 1959, Jesus and the servant: The influence of the servant concept of Deutero-Isaiah in the New Testament, S.P.C.K, London.

Kovács, F.Z., 2006, 'The covenant in Luke-Acts', MTh dissertation, North-West University, Potchefstroom.

Litwak, K.D., 2005, Echoes of Scripture in Luke-Acts: Telling the history of God's people intertextually, T \& T Clark, Edinburgh. 
Mallen, P., 2008, The reading and transformation of Isaiah in Luke-Acts, T \& T Clark, London.

Marshall, I.H., 1971, Luke: Historian and theologian. Zondervan, Grand Rapids, MI.

Martin-Achard, R., 1962, A light to the nations: A study of the Old Testament conception of Israel's mission to the world, transl. J.P. Smith, Oliver and Boyd, Edinburgh.

Mattill, A.J., 1975, 'The Jesus-Paul parallels and the purpose of Luke-Acts: H.H. Evans reconsidered', Novum Testamentum 17(1), 15-46. http://dx.doi. org/10.1163/156853675X00103

Minear, P.S., 1976, To heal and to reveal: The prophetic vocation according to Luke, The Seabury Press, New York, NY.

Morgenthaler, R., 1949, Die lukanische Geschichtsschreibung als Zeugnis: Gestalt und Gehalt der Kunst des Lukas, 2 vols, Zwingli Verlag, Zürich. PMid:18140919

Nelson, P.K., 1994, Leadership and discipleship: A study of Luke 22:24-30, Scholars Press, Atlanta, GA.

Oswalt, J.N., 1998, The book of Isaiah 1-66, 2 vols, William B. Eerdmans, Grand Rapids, $\mathrm{Ml}$.

Oswalt, J.N., 1991, 'The mission of Israel to the nations', in W.V. Crockett \& J. Sigountos (eds.), Through no fault of their own? The fate of those who have never heard, pp. 85-95, Baker Book House, Grand Rapids, MI.

Parsons, M.C. 1987, 'The departure of Jesus in Luke-Acts: The ascension narrative in context', Journal for the study of the New Testament 21, JSOT Press, Sheffield.

Patte, D., 1990, The religious dimensions of Biblical texts: Greimas's structural semiotics and Biblical exegesis, Scholars Press, Atlanta, GA.
Patte, D. \& Parker, J.F., 1980, 'A structural exegesis of Genesis 2 and 3', Semeia 18 $55-75$.

Patte, D. \& Patte A., 1978, Structural exegesis: From theory to practice, Fortress Press, Philadelphia.

Prince, G., 2003, Dictionary of narratology, University of Nebraska Press, Lincoln.

Puskas, C.B., 2009, The conclusion of Luke-Acts: The significance of Acts 28:16-31, Pickwick Publications, Eugene, OR.

Richard, E., 1982, 'The creative use of Amos by the author of Acts', Novum Testamentum 24(1), 37-53. http://dx.doi.org/10.1163/156853682X00079

Routledge, R., 2004, 'Is there a narrative substructure underlying the book of Isaiah?', Tyndale Bulletin 55(2), 183-204.

Spencer, P.E., 2007, 'The unity of Luke-Acts: A four-bolted hermeneutical hinge', Currents in Biblical Research 5(3), 341-366. http://dx.doi.org/10.1177/1476993X07077967

Steck, H.O., 1967, Israel und das gewaltsame Geschick der Propheten, Wissenschaftliche Monographien zum Alten und Neuen Testament 23, Neukirchener Verlag, Neukirchener.

Wasserberg, G., 1998, Aus Israels Mitte - Heil für die Welt: Eine narrativ-exegetische Studie zur Theologie des Lukas, De Gruyter, Berlin.

Wenk, M., 2000, Community-forming power: The socio-ethical role of the Spirit in Luke-Acts. Sheffield Academic Press, Sheffield.

Wright, N.T., 1992, The New Testament and the people of God, vol. 1, Fortress Press, Minneapolis, MN. 